\title{
Andruana Ann Jean Jimmy: A Mapoon leader's struggle to regain a homeland ${ }^{1}$
}

\author{
GEOFF WHARTON²
}

Andruana Ann Jean Jimmy (1912-91), Aboriginal leader, land rights activist, local government councillor and poet, was born on 30 September 1912 near the Pennefather (formerly Coen) River, south-west of Mapoon Presbyterian mission, Queensland (established 1891), youngest of three children of Philip of the Rakudi People—probably a Yupangathi (Yupungathi) clan group—and Lorna (aka Maggie). ${ }^{3}$ Jean's traditional language name in the Yupngayth (Yupungayth) language was Andruana, meaning wattle flower, a name associated with being

\footnotetext{
1 Cultural warning: Readers of this article should be aware that some of the church and government archival records and publications of the nineteenth and twentieth centuries contain words that are now considered offensive. Such words may appear in the article where a quote is made from archival records or publications. The history also refers to persons who have passed away and to incidents of a distressing nature.

2 The author thanks Mrs Christine Cooktown, Ms Linda Cooktown and Ms Linda McLachlan for their support during the research for this article. Special appreciation goes to Ms Florence Charger, the late Mr Dan Cooktown, the late Mrs Harriet Flinders, Mrs Ruth Hennings and Mrs Florence Luff for generously sharing their personal memories of Jean Jimmy. Staff of the Community and Personal Histories section, Queensland Department of Aboriginal and Torres Strait Islander Partnerships, as well as the Mitchell Library, Queensland Presbyterian Archives, Queensland State Archives and the State Library of Queensland all provided valuable advice and information. Appreciation also to Darryl Bennet and the referees for their welcome editorial improvements to the article.

3 The recording of Aboriginal people's names by Queensland Government officials and missionaries was haphazard during the mission era. It is common for several spelling variants of the same person's names to appear in church and official records. Frequently, traditional language names of the first generation were ignored by the missionaries and replaced with a single Christian name, which then became the family surname in the second generation. Sometimes the wife's surname would be assumed from the husband's first name, hence in some records, Jean Jimmy is recorded as Jean Gilbert, after her husband, Gilbert Jimmy. Jean's birth date was derived from her grave headstone at Mapoon. At the time of Jean Philip's birth, mission superintendents in Queensland were not required to register births, marriages or deaths of Indigenous residents of the mission reserve. Although the Mapoon missionaries did maintain a church baptisms, births, marriages and death register, now held by the manuscript collections of the Mitchell Library, Sydney, Jean Philip's birth does not appear to be recorded in that register (possibly because she was born on her father's traditional country away from the mission) or in the records of the Queensland Registrar-General. Mapoon Presbyterian Mission Station, Register of baptisms, births, marriages and deaths, Box MLK 2544, MLMSS 1893 Add-on 1173, Board of Ecumenical Mission and Relations (BOEMAR) Records, (Microfilm CY Reel 3568), Mitchell Library, State Library of New South Wales, Sydney.

Jean's birthplace is stated as Coen River on her marriage certificate and her parents' names on that certificate are stated as Philip and Maggie. Marriage certificate for Jean Philip and Gilbert Jimmy, 29 August 1933, Registration no. 1933/27111214, Queensland Registrar-General's Office. Coen River was renamed the Pennefather River in 1894, but it continued to be known locally as the Coen River by Mapoon people and so-described on Admiralty hydrographic charts until the 1960s. For further information, see Queensland Place Names Online Search website at www.derm.qld.gov.au/property/placenames/details.php?id=47589.
} 
a strong woman through the power of the tree. ${ }^{4}$ Jean had one brother, Richard, who was born c. 1898 and became known as Dick Luff during the 1930s, and one sister, Maggie, born c. 1910, who married Frank Don at Mapoon Presbyterian mission on 12 December 1925.5

Mapoon community was established as the Batavia River Presbyterian mission on the western shores of Port Musgrave on Cape York Peninsula by Moravian missionaries: Rev. James Gibson Ward (1857-95) and Rev. John Nicholas Hey (1862-1951), who worked under contract to the Presbyterian Churches of Australia. Ward and Hey married Irish Moravian sisters, Matilda Hall Barnes (1861-1953) and Mary Anne (Minnie) Barnes (1869-1970). Matilda Ward-known in the mission as Aunt Tilly-started a school in 1892 and continued as the mission teacher until her retirement in 1917. Following Ward's death in January 1895, Hey became the mission superintendent, continuing in this role until he and Minnie retired in October 1919.

\footnotetext{
In sworn evidence before the chief justice of the Supreme Court of the Australian Capital Territory, Sir Richard Blackburn, on 1 September 1983, Jean Jimmy stated that her father's country was on the south side of the Pennefather River. Jean Jimmy, transcript of evidence given in Comalco Ltd v. Australian Broadcasting Commission, Supreme Court of the Australian Capital Territory, 1 September 1983, 3428, 3430, Cape York Collection, Hibberd Library, Weipa. During this evidence, at p. 3428, Jean also stated that she was 'from the Yupagnatte [Yupangathi/Yupungathi] tribe'. There are various spellings of the language and language group. The Australian Institute of Aboriginal and Torres Strait Islander Studies Mura catalogue lists Yupangathi works under the descriptor 'Nggerigudi/Yupngayth people (Y19) (Qld SD54-03)'.

Jean's father, who was named Philip, or Phillip, or sometimes Philip the Evangelist, was photographed and recorded by W. E. Roth in October 1899, who stated that Philip was from the 'Rá Kudi [tribe] —south side of Pennefather River', Commissioner of Police anthropometric chart, registered number 43, compiled at Mapoon by W. E. Roth, Queensland Home Secretary correspondence bundle, 1899, Item ID 271658, Queensland State Archives (QSA). A Presbyterian Church publication dated c. 1924 contains a photograph of Jean's father with the caption, 'Philip, the Evangelist, an Elder of Mapoon Church and S.S. [Sunday School] Superintendent, Batavia [outstation]'. Presbyterian Church of Queensland, 'Missions to the Aboriginals', 1924, 1. Printed pamphlet held in File D.5.1, by Presbyterian Church Archives, Brisbane.

The death certificate for Lorna Phillips [Philip] records that her two children at the time of her death were Maggie Don, 43 years, and Jean Gilbert, 40 years. Death certificate for Lorna Phillips, 1 December 1953, Registration no. 1953/45755923, Queensland Registrar-General's Office. In an interview for the Napranum Cha newspaper in 1986, Jean noted that her 'mother came from Batavia'. This may mean that her mother's traditional lands were in the vicinity of the old Batavia outstation or somewhere along the Batavia (now Wenlock) River. 'M.A.P'., Napranum Cha: Weipa South, no. 3 (December/January 1986): 24. A senior family member has also indicated that Lorna was a Yupangathi woman. Mrs F. Luff, pers. comm. to author, 16 November 2013.

4 Jean's language name was given to the author by Ms Florence Charger and the cultural meaning was provided by Mrs Florence Luff to the author on 16 November 2013.

5 Information about Jean's siblings has been obtained from: Marriage certificate for Frank Dan [Don] and Maggie Philip, Mapoon, 12 December 1925, Registration number 1925/3658880, Queensland RegistrarGeneral's Office; Marriage certificate for Dick Phillip and Aggie, Mapoon, 3 May 1930, Registration number 1930/17241071; Death certificate for Lorna Phillips, 1 December 1953, Registration number 1953/45755923, Queensland Registrar-General's Office.
} 
Mapoon country is richly endowed with coastal lagoons, tall eucalypt woodlands, paperbark woodlands and vine forests, as well as wild river estuaries and coastal waters with a wide variety of fresh and marine fish species, abundant bird life and many species of plants that provide natural bush foods and medicines. When the European missionaries came from the cool green farming lands of Germany and Ireland to the hot and humid tropical climate of Queensland in the pre-wet season of November 1891, they faced many trials, including tropical fevers, mosquitoes and an environment most strange to them. For the Aboriginal people who came to know these strangers, there were in turn many challenges in interacting with Europeans who could not understand their traditional languages, in missionary antipathy and fear of traditional cultural practices and in an underlying arrogance towards the Aboriginal way of life. Writing about his experience at Mapoon, Hey commented: 'Many of the old superstitious beliefs, though subdued, were not slain, and the appearance and reappearance of these dark elements often caused great disturbances and distress'. ${ }^{6}$

By late 1892, Batavia River mission became known by the Tjungundji language name Mapoon, meaning 'place where people fight on the sandhills'. For the first decade, Mapoon was a mission to Aboriginal people of the local area, particularly the Tjungundji and Yupangathi people; later people came in from the Pine River to the south, the Skardon River from the north, and the country to the east of the Batavia (now Wenlock) and Ducie rivers. Queensland's Northern Protector of Aboriginals, Dr Walter Roth, decided in 1901 to remove children of mixed-descent from their families on cattle stations or near towns in the Gulf country. He and later protectors sent these children to be raised by the Mapoon missionaries as boarders in the mission dormitories. Although the government explained this as a form of child protection, it meant that they were effectively stolen from their parents by the police and many never saw their blood relatives again. Mapoon Traditional Owners befriended the removed children and gave them cultural identities to protect them in strangers' country. A third wave of migration to Mapoon mission included people from the South Sea Islands, such as Samoa, New Hebrides (now Vanuatu) and the Solomon Islands. They were employed by the Presbyterian Church in the early 1900 s to assist the missionaries as boat crew, carpenters and gardeners.

6 J. N. Hey, A Brief History of the Presbyterian Church's Mission Enterprise among the Australian Aborigines (Sydney: New Press, 1931), 29. 
At the time of Jean's birth, Mapoon had been operating as a mission for 21 years. Although some tribal groups had come to subsist in the sedentary village lifestyle encouraged by Hey, others continued to live on their traditional lands. Like most Presbyterian mission children of her time, Jean was sent to live in a girls' dormitory from the age of about five until she left school at $14 .^{7}$ She rarely saw her parents during those years, because her father was an evangelist to traditional people near the Batavia outstation some 25 kilometres south of Mapoon (Figure 1). ${ }^{8}$ However, in her late teens she was able to spend more time with them and fondly recalled learning about traditional customs and knowledge from her mother. Jean later spoke about her mother's influence:

I don't know how old I was when my mother showed me all the bush medicine ... The first one she showed me was a grass. 'If you ever get married and you are walking through bloodwood country there is no water, but this grass I'm going to show you holds water."

It is uncertain which species of grass Jean was referring to, but there are tall woodlands near Batavia outstation containing bloodwoods such as Corymbia nesophila and C. polycarpa, with a grassy understorey. This traditional lifestyle had a strong spiritual dimension that is reflected in Jean's poetry and writing; for example, to avoid being struck by lightning: 'The old people [ancestors] say that pandanus is the lightning's cousin ... If you are walking on the plain, just go and stand under the pandanus if there is lightning'. ${ }^{10}$ To Mapoon people, every living creature and every part of the landscape has a spiritual dimension and that in turn provides a holistic strength to the people. Jean explained in an Indigenous book published for the Australian Bicentenary: 'We love to live at Mapoon, my heart is there because it's our country. It's healthy, we never get sick there'. ${ }^{11}$

\footnotetext{
7 Jean Jimmy, interview broadcast in the documentary film Welcome to My Home (Brisbane: Comalco Limited, 1984).

8 Jean Jimmy, interview broadcast in the documentary film Welcome to My Home. In his annual report for 1931, the Mapoon superintendent, Rev. Percy Currell recorded that 'old Don and Philip are conducting regular worship in the bush with the Batavian tribe'. P. R. Currell, 'Mapoon Mission Station Annual Report for 1931', Presbyterian Outlook 15, no. 3 (September 1932): 20.

9 Interview with Jean Jimmy, 'M.A.P'. Napranum Cha: Weipa South, no. 3 (December 1985/January 1986): 24.

10 Interview with Jean Jimmy, Napranum Cha, 25.

11 Ann Jean Jimmy, quoted in Penny Taylor, ed., After 200 Years: Photographic Essays of Aboriginal and Islander Australia Today (Canberra: Aboriginal Studies Press, 1988), 272.
} 


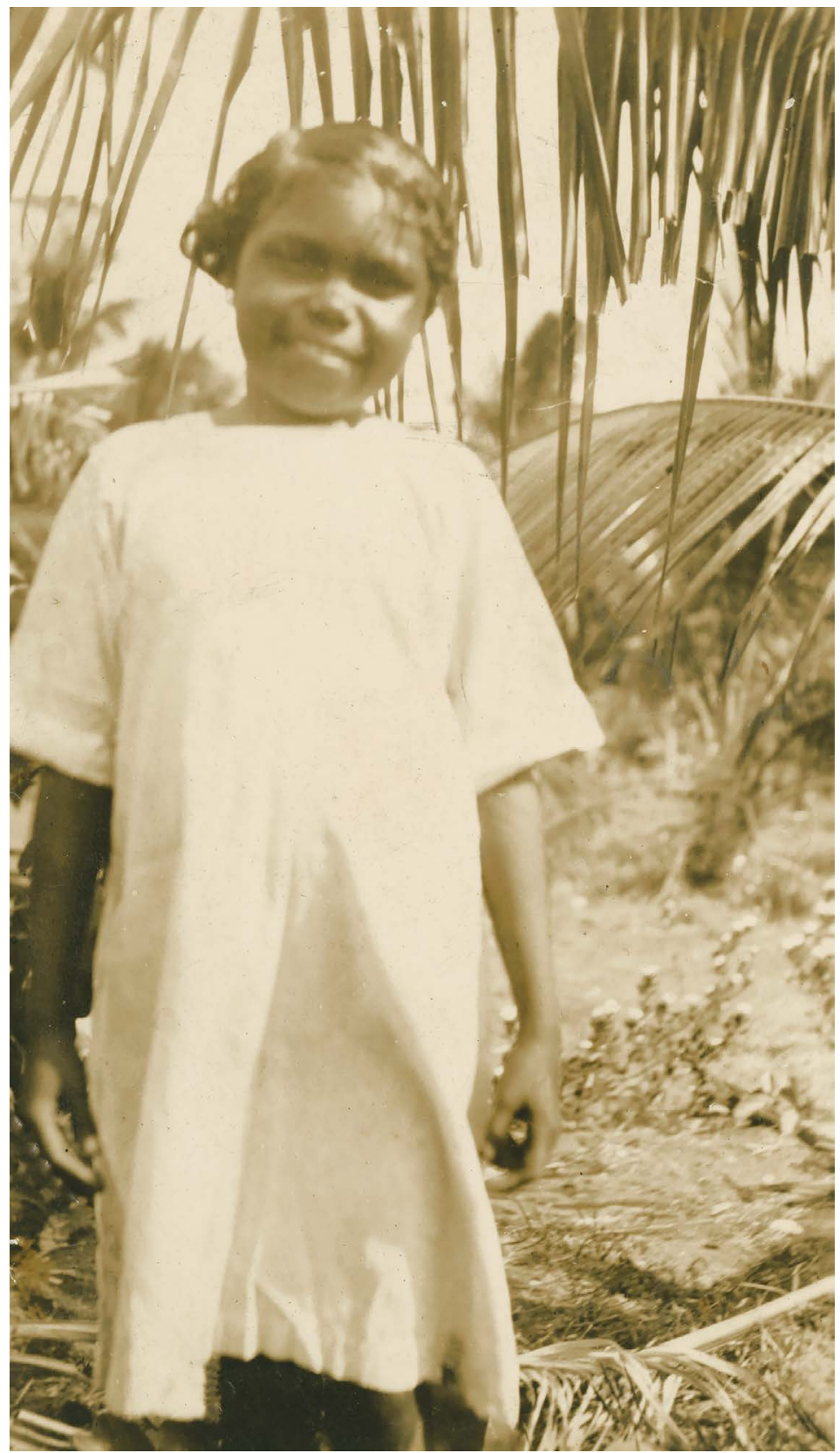

Figure 1: Jean Philip aged about eight or nine at Mapoon mission, c. 1921/22.12

Source: State Library of Queensland, negative number 109080, original print held in the Uniting Church Collection, reference code 2769, box 3923, SLQ.

12 This photograph probably was taken by Miss Esther Finger, teacher at Mapoon from May 1921 to May 1922. 'Mission notes', Presbyterian Outlook 4, no. 34 (May 1921): 17. The caption on the reverse of the photograph held by the State Library of Queensland states: 'Jean Philip daughter of Philip the Evangelist'. 
The missionaries taught the girls crochet, sewing and other handcrafts, as well as domestic science. In later life, Jean recalled with sadness that the mission teachers 'cut out our language', leading to the loss of spoken traditional languages at Mapoon. This was due to missionaries facing difficulties with the number of different languages spoken at the mission, and government policy that only English was to be taught in mission schools. ${ }^{13}$ During the first decade or so, the missionaries endeavoured to learn and speak in the local languages, but this had been abandoned by the time Jean attended school. ${ }^{14}$ Every part of daily life at the mission was strictly controlled by the superintendent, who was not only an evangelist, but also had statutory approval to control people's behaviour, with powers such as the infliction of corporal punishment on any Aboriginal person under the age of $16 .^{15}$

At the Mapoon Presbyterian mission church on 29 August 1933, Jean married Gilbert Jimmy, aged 27, a sailor who crewed on pearl-shell industry luggers and on the church's vessels. ${ }^{16}$ Gilbert was born at Mapoon on 6 July 1906, son of Jimmie (aka Jimmy) and Georgina Jimmy (née Lee). ${ }^{17}$ Towards the end of World War II, Jean and Gilbert moved to Thursday Island, where Gilbert was employed by the coastal trading firm Burns Philp, and Jean was employed in domestic work. ${ }^{18}$ During the early 1950s Mapoon mission suffered from low financial support by Presbyterian congregations, while the Queensland Government was unwilling to fund the redevelopment of the community infrastructure. Traditional Owners and community members were excluded from a meeting held between church and government officials at Mapoon in April 1954, at which a decision was made to

13 For a description of the languages of the Mapoon region, see Terry Crowley, 'The Mpakwithi Dialect of Anguthimri', in Handbook of Australian Languages: Volume 2, ed. R. M. W. Dixon and Barry J. Blake (Canberra: Australian National University Press, 1981), 146, 148-50; Matilda Ward, undated manuscript, contained in Miscellaneous records re Mapoon Mission. Qld., c.1895-c.1967, BOEMAR records, MLMSS 1893/11 Items 1-16, CY Reel 2981, Mitchell Library, Sydney. See also Hey, A Brief History of the Presbyterian Church's Mission Enterprise, 30; and Geraldine MacKenzie, Aurukun Diary: Forty Years with the Aborigines (Melbourne: The Aldersgate Press, 1981), 47.

14 For example, J. G. Ward's (posthumous) and J. N. Hey's 'Coen R[iver]' and 'Mapoon R[iver]' vocabularies published in John Mathew, Eaglehawk and Crow: A Study of the Australian Aborigines, Including an Inquiry into Their Origin and a Survey of Australian Languages (London: Nutt, 1899), 208-72. Coen River was the European name used for the Pennefather River between 1802 and 1894. Mapoon River probably refers to Port Musgrave and the Batavia (later renamed Wenlock) River. See also N. Hey, 'An Elementary Grammar of the Nggerikudi Language', North Queensland Ethnography Bulletin No. 6 (Brisbane: Government Printer, 1903).

15 'Regulation 8 pursuant to the Aboriginals Protection and Restriction of the Sale of Opium Acts, 1897 to 1901', Queensland Government Gazette 85, no. 120 (11 November 1905): 1037.

16 Marriage certificate for Jean Philip and Gilbert Jimmy, 29 August 1933, Registration no. 1933/27111214, Queensland Registrar-General's Office. Vessels that Gilbert crewed on included Dinton, 1926; Acton, 1928; Willow, 1929; Acton, 1930 and 1932; and Marston, 1933. Seamen's Discharge Register 1926-1934, Shipping Master, Thursday Island, Item ID 516410, QSA. He also crewed on the Linton in 1939. Seamen's Discharge Register 1934-1939, Shipping Master, Thursday Island, Item ID 516411, QSA.

17 Gilbert Jimmy's birth date and parents are recorded in his Department of Aboriginal and Island Affairs personal file, 8G/267, Box 334, Item ID 725422, QSA.

18 Jean Jimmy, transcript of evidence given in Comalco Ltd v. Australian Broadcasting Commission, Supreme Court of the Australian Capital Territory, 1 September 1983, 3424-25. 
abandon Mapoon and send the residents to Weipa Presbyterian mission. ${ }^{19}$ Few of the officials had any understanding of the deep cultural and spiritual connections that the people had for their traditional land and sea, so the stage was set for a long and bitter war of attrition. This was further complicated by the likelihood of largescale industrial development following the discovery of economic bauxite deposits by the geologist Harry Evans in July and October 1955.

In about 1958 Jean and Gilbert returned to live at Mapoon and were alarmed to encounter a new mission administration led by the recently ordained Rev. Garth Filmer, who was unsympathetic to the community's desire to remain. ${ }^{20}$ In that year, the Queensland Government issued mining company Commonwealth Aluminium Corporation Pty Limited (Comalco) with a special bauxite mining lease under the terms of a favourable state agreement Act, which did not recognise any prior land rights for Indigenous people of the region and made no provision for the loss of their reserve lands. ${ }^{21}$ One of the effects of the Act was that over one-third of the former Mapoon Aboriginal Reserve of 3,345 square miles was extinguished, and the reserve was reduced to 2,115 square miles. Under the terms of its reserve, the church was just a trustee for land reserved by the government and thus was unable to bring any legal action to protect the land interests of the Traditional Owners. ${ }^{22}$ Jean held the view that Mapoon was being closed to allow the miners easy access to her people's lands and later, during the 1960s and '70s, persuasively presented her opinion to the Australian public.

Jean and Gilbert, along with other community elders, vigorously campaigned against Mapoon's closure until their forced removal in 1963. They did this in the face of draconian state legislative powers still available to the mission superintendent to censor a resident's mail and to inflict punishment for disobeying his orders. ${ }^{23}$ The legislation was used by two consecutive directors of native affairs, Cornelius O'Leary (1897-1971) and Patrick James Killoran (1922-2010), to override the community's opposition to the closure. ${ }^{24}$ By mid-1961, the government had commenced building a new village at Mandingu (Hidden Valley) near Bamaga,

19 Report of Mapoon Conference held at Mapoon on Thursday and Friday, 8 and 9 April 1954, File AQ/7, BOEMAR Records, Box 19, MLMSS 1893 Add-on 1872, Mitchell Library, Sydney.

20 Jean Jimmy, interview with author, Weipa South [Napranum], 1 July 1975. A digital copy of this interview was made by ABC Radio National in 2012 and is held in the Cultural Keeping Place at Mapoon. Geoffrey Wharton, 'The Day They Burned Mapoon: A Study of the Closure of a Queensland Presbyterian Mission' (BA Hons thesis, University of Queensland, 1996), 25. See also G. L. Filmer, St Paul's Presbyterian Church, Gordonvale, letter to editor, Cairns Post, 4 December 1963, 7.

21 Special Bauxite Mining Lease No. 1 (now Mining Lease ML7024) commenced operation on 1 January 1958. Commonwealth Aluminium Corporation Pty. Limited Agreement Act 1957 (Qld), sch. 1, cl. 8(a).

22 Queensland Government Gazette 198, no. 88 (5 July 1958): 1789.

23 'The Aboriginals Regulations of 1945', pursuant to The Aboriginals Preservation and Protection Act of 1939, Queensland Government Gazette 164, no. 90 (23 April 1945): 1063-73.

24 Rosalind Kidd, The Way We Civilize: Aboriginal Affairs - The Untold Story (St Lucia: University of Queensland Press, 1997), 216-23. 
about 200 kilometres north-east of Mapoon. ${ }^{25}$ From late 1961 until mid-1963, some Mapoon people moved voluntarily to this community — which became known as New Mapoon-but the Jimmy family and many others did not want to move away from their homeland.

The fight against the closure was supported by Joe McGinness (1914-2003), a senior figure in the Federal Council for the Advancement of Aborigines and the secretary of the Cairns Aboriginal \& Torres Strait Islanders Advancement League. ${ }^{26}$ In late 1962 McGinness issued a pamphlet, developed by Leonard Webb, entitled 'They have made our rights wrong', which set out the concerns of the Mapoon community. ${ }^{27}$ Mapoon people living in Cairns held several street protests and distributed the league's pamphlet, but few in Australian society were listening. ${ }^{28}$ An unsympathetic Queensland media reported a statement by the Presbyterian Church that the Advancement League 'was sponsored by the Trades and Labor Council, where known Communists were entrenched'. ${ }^{29}$ In the Cold War era of the early 1960s, such derogatory statements by church and government officials easily distracted the media and public from supporting controversial social issues.

Determined to break the Jimmy family's opposition to the closure, Killoran sent a visiting magistrate, Bernard Scanlan, to inspect Mapoon on 20 June 1963. During his interview with Scanlan, Gilbert Jimmy, at that time head councillor, spoke strongly against the church's demands that Mapoon people should move north to the Bamaga area, but to no avail. ${ }^{30}$ Killoran used Scanlan's negative report about the community to justify his subsequent actions. On 15 November 1963 two Queensland police officers arrived at Mapoon on the Queensland Government vessel Gelam and executed a removal order for 'disciplinary' and 'medical' reasons under section 22 of the Aboriginals Preservation and Protection Act. ${ }^{31}$ The order was issued with the prior knowledge of the Queensland director-general of education and the general secretary of the Australian Presbyterian Board of Missions, Rev. James

\footnotetext{
25 The language name for the place where New Mapoon community was built is Mandingu. Injinoo Community Council, Injinoo Handbook (Injinoo, Qld: Injnoo Community Council, c. 1994). P. J. Killoran, Thursday Island, to Secretary, Aboriginal and Foreign Missions Committee, Brisbane, 5 July 1961, AFMC/CF 1961, Box MLK 2543, BOEMAR Records, Mitchell Library.

26 Sue Taffe, 'The Cairns Aborigines and Torres Strait Islander Advancement League and the Community of the Left', Labour History 97 (2009): 160-61.

27 Taffe, 'The Cairns Aborigines and Torres Strait Islander Advancement League', 160-61.

28 Ruth Hennings (née Warrack), speech at the opening of the Jean Jimmy Land \& Sea Centre, Mapoon, 16 November 1963.

29 'Natives Moving to Cape', Courier Mail, 24 January 1963, 8.

30 B. J. Scanlan, Visiting Justice, Thursday Island to Director of Native Affairs, Thursday Island, 26 June 1963, Director of Native Affairs Office (DNAO) File 1A/343, Visiting Justice-Bamaga and Gulf Missions Lockhart River, Mapoon \& Weipa, Item ID 337346, QSA.

31 Director of Native Affairs to Officer-in-Charge, Police Station, Thursday Island, 14 November 1963, enclosing Removal Order No. 32/63, DNAO File 6D/25, Item ID 511511, QSA. M.V. Gelam was a motor vessel operated by the Sub-Department of Native Affairs.
} 
Stuckey (1911-2000). ${ }^{32}$ It was served by the police upon 11 adult Mapoon residents, including Jean and Gilbert Jimmy, and some of their homes were destroyed. ${ }^{33}$ Aboriginal people subject to the Queensland legislation at that time had no right of appeal against a removal order. The Jimmy family, Jean's daughter Constance and her family, Jean's brother Richard Luff and wife Victoria, Jean's sister Maggie Don and husband Frank, along with 14 other Mapoon men, women and children were aboard the Gelam when it sailed for Red Island Point. Jean recalled her feelings when they left Mapoon on 17 November:

The swamps were all stirred up-scared millions of birds. When we looked around we couldn't see the sun. The harbour was just covered with birds, all sorts of birds and the Gelam was sailing just under the shadow. When we came up right on the Cullen Point now the bow was just about to come out and the birds formed V, capital V ... Oh it was marvellous, you know we looking up to the sky and I said gee ... what these birds ... mean? I said maybe in ... years to come ... we'll fight it, fight and win the victory because it's more like a big fight between us and the Director. ${ }^{34}$

Jean's commitment to the fight for her traditional homeland was sustained for the rest of her life. The journalist Claire Dunne, who travelled to Mapoon and recorded interviews with Jean in the early 1980s, found her sense of purpose remarkable, combining her traditional spirituality with the Christian religion she had been taught in the dormitory:

The man above who created you, he have a job for you and he push you. If not him, its the spirits of our people make it that way. God sees I must be the promised one who speaks on behalf of my people. ${ }^{35}$

32 Director of Native Affairs to Director-General of Education, 5 July 1963, DNAO File 6D/25, Item ID 511511, QSA. Stuckey stated: 'There is the proposal that the major trouble movers shall at the recommendation of the stipendiary magistrate be removed which would mean that the situation ought not be difficult'. J. M. Stuckey, General Secretary, Australian Presbyterian Board of Missions, Sydney to W. Norgate, Presbyterian Missions Agency, Thursday Island, 5 July 1963, Aboriginal and Overseas Missions Committee correspondence file for Mapoon, 1963, Queensland Presbyterian Archives. Rev. James Stuckey served as General Secretary, Australian Presbyterian Board of Missions from 1960 to 1972 . He passed away on 18 October 2000. Ted Stuckey, 'James Stuckey: Missionary 1911-2000', Sydney Morning Herald, 13 December 2000, 34.

33 Director of Native Affairs to Officer-in-Charge, Police Station, Thursday Island, 14 November 1963, enclosing Removal Order No. 32/63, DNAO File 6D/25, Item ID 511511, QSA; Director of Native Affairs, Thursday Island to Director of Native Affairs, Brisbane, 14 November 1963, DNAO File 6G/20, Part 2, ID506593, QSA; Aboriginal people subject to the Aboriginals Preservation and Protection Act 1939 (Qld) had no legal right of appeal against a removal order under the Act.

34 Jean Jimmy, interview with author, Weipa South [Napranum], 1 July 1975.

35 Claire Dunne, People Under the Skin: An Irish Immigrant's Experience of Aboriginal Australia (Carlingford, NSW: Lotus Publishing House Pty Limited, 1988), 73. Clare Mary Elizabeth Dunne OAM (b. 1937) was a broadcaster and television personality who was involved with the development of the Special Broadcasting Service. She met Jean in Cairns while researching the lives of six prominent Aboriginal people for a proposed television series in 1980-81. Dunne's chapters (pp. 52-74) about her time with Jean are an insightful record of the Mapoon community's experiences. 
When Jean and Gilbert arrived at New Mapoon there was a severe shortage of housing, due to poor planning by Queensland Government officials. The Presbyterian padre, Rev. George Taylor, reported to the church headquarters with disgust in October 1964:

When Mr Killoran was here some time ago, he admitted that what Jean Gilbert told the conference at Canberra, about the Mapoon people being forced to leave Mapoon was true ... The people arrived in November and December last year to a situation which in my opinion was scandalous. They had no houses to go into, and many promises that had been made to them had not been fulfilled. They are still badly overcrowded in the houses and this has been the cause of many visits by me to the Superintendent's office here. ${ }^{36}$

The Jimmys eventually settled into life at New Mapoon but Jean continued to press for a return to her homeland. In 1964, she travelled 3,000 kilometres to Canberra to attend the annual conference of the Federal Council for the Advancement of Aborigines and Torres Strait Islanders. ${ }^{37}$ She spoke about the attempts by the community to be self-sufficient and how the government broke the morale of the community. ${ }^{38}$ The conference secretary, Pauline Pickford, reported that Jean was 'a most capable, dignified Aboriginal woman'. ${ }^{39}$ Jean continued to lobby the Australian public through attendance and participation in national conferences during the next 10 years. ${ }^{40}$

Following the advent of the Aborigines and Torres Strait Islanders Affairs Act 1965, the Queensland director of Aboriginal and Torres Strait Islander Affairs endeavoured to increase the involvement of elected Aboriginal councillors in the management of their communities. At the first triennial election held in November 1969, Jean Jimmy recorded the highest number of votes and subsequently was elected chair of the New Mapoon Council. ${ }^{41}$ She served as chair until her resignation on 7 June 1971, prior to new council elections. ${ }^{42}$ In about 1974 Jean and Gilbert moved to the Weipa South community, which brought them closer to Mapoon. The construction

\footnotetext{
36 G. W. Taylor to Secretary, Aboriginal and Overseas Missions Committee, 11 October 1964, New Mapoon File, Aboriginal and Overseas Missions Committee Correspondence File, 1964, Queensland Presbyterian Archives. 37 Council for Aboriginal Rights (Victoria). Summary of the 7th Annual Conference of the Federal Council for Aboriginal Advancement, Carton Y603 (Box 5), Federal Council for the Advancement of Aborigines and Torres Strait Islanders Records, MLMSS 2999, Mitchell Library, Sydney.

38 Sue Taffe, Black and White Together: FCAATSI: The Federal Council for the Advancement of Aborigines and Torres Strait Islanders 1958-1973 (St Lucia: University of Queensland Press, 2005), 191.

39 Taffe, Black and White Together, 192.

40 For example, Federal Council for Advancement of Aborigines and Torres Strait Islanders, 9th Annual Conference on Aboriginal Affairs, Canberra, April 1966; and Aboriginal and Islander Women's Conference for International Women's Year, James Cook University, 1975.

41 R. Trundle, Manager, Department of Aboriginal and Island Affairs, Bamaga, to Director, Department of Aboriginal \& Island Affairs, 2 December 1969, File 9M/81, Administration-Bamaga-New Mapoon, Director of Aboriginal and Island Affairs correspondence files, Item ID 507740, QSA.

42 Acting Manager, DAIA, Bamaga, to Director, DAIA, Brisbane, 2 July 1971, File 9M/81, AdministrationBamaga - New Mapoon, Director of Aboriginal and Island Affairs correspondence files, Item ID 507740, QSA.
} 
of a major bridge over the Mission River by Comalco in 1971 made it possible to drive by bush tracks from Weipa to Mapoon in a few hours. Jean contacted Jerry Hudson, a Mapoon man who was head stockman at Aurukun Presbyterian Mission, and invited him and his wife Ina to return and lead their people back to Mapoon. ${ }^{43}$ First settling in May 1974, the Hudsons were joined by other families in September, constructing their homes from bush timbers and sheets of corrugated iron remaining from the original villages.

While much of her energy in later life was devoted to the redevelopment of her beloved Mapoon, Jean also was recognised as a leader by the people of her adopted community at Weipa South (now Napranum). She was elected a councillor of the Weipa South Council on 15 January 1982 and served one term as chair, from 18 January 1982 to 30 March $1985 .{ }^{44}$ Jean Jimmy was probably the only Indigenous woman in Queensland and possibly Australian history to have been chair of the elected councils of two separate communities. ${ }^{45}$ During her term at Weipa South, she oversaw the early stages of the transition from government control to a selfmanagement model under the Community Services (Aborigines) Act 1984 (Qld).

In 1984 Jean worked with community members to establish the Marpuna Community Aboriginal Corporation under the Aboriginal Councils and Associations Act 1976(Cth), and was elected the first chairperson of the corporation, ${ }^{46}$ which was formed to assist Mapoon people back to their lands and to provide a path towards self-management of their community. ${ }^{47}$ The corporation was successful in fulfilling its objectives and was succeeded by the Mapoon Aboriginal Council in 2000.48 Jean never tired of advocating Mapoon people's cause. Appearing before the Senate Standing Committee on Constitutional and Legal Affairs at Weipa in 1981, she pleaded for her people to be able to return to Mapoon 'and set up their culture again. Mapoon did great things

\footnotetext{
43 J. P. Roberts, ed., The Mapoon Story by the Mapoon People (Fitzroy, Vic.: International Development Action, 1975), 16-17.

44 D. W. Hanlon, Manager, DAIA, Weipa to Director, DAIA, Brisbane, 5 January 1982 and minutes of Weipa South Council meeting, 18 January 1982, Administration-Weipa Aboriginal Council, File 16A/25 Part 2, Item ID 509022, QSA. Jean Jimmy's chaired her last Weipa South Council meeting on 20 March 1985. Minutes of Weipa South Council, 20 March 1985, AIA-Weipa-Administration Aboriginal Council, File 16-019-001, Item ID 646022, QSA. Alberta Cannon, Council Clerk, telegram to Department of Community Services, Brisbane, 1 April 1985, File 16-019-001, Item ID 646022, QSA.

45 New Mapoon (1969-71) and Weipa South (1982-85).

46 Registrar of Aboriginal Corporations, Certificate of Incorporation of an Aboriginal Association, Marpuna Community Aboriginal Corporation, 17 December 1984, document on website of the Office of the Registrar of Indigenous Corporations, accessed 9 April 2012, www.oric.gov.au. Silver Blanco, Chairman, Marpuna Community Aboriginal Corporation, personal comment to author, 1989.

47 Silver Blanco, [Notes on the formation of the Marpuna Community Aboriginal Corporation], 28 July 1989. Copy of document held by the author.

48 Weipa Bulletin, no. 1689 (31 March 2000): 1.
} 
for the Army and Air Force during wartime. But all the people got was the destruction of Mapoon' ${ }^{49}$ Despite this deep sense of betrayal, Jean still was prepared to give to the nation when she considered the cause appropriate.

As a young woman, Jean was taught about bush foods and medicines by her mother and she generously shared that knowledge not with only later generations of her community, but also with the Australian Army's survival specialist Captain Les Hiddins, who recorded her information at Mapoon in 1983 (Figures 2 and 3). ${ }^{50}$ Hiddins was conducting studies of Indigenous survival resources across northern Australia for the Australian Army, and had met Jean and other community elders during research in the Weipa-Mapoon area. Jean recalled how her mother had given her the ancient traditional method for treating blind boils with the leaves of a creeping vine: 'You have to boil the leaves or warm them against the fire. Then you just put them on the boil to make it better'. ${ }^{51}$

The traditional teaching of her parents inspired Jean throughout her life and her writing and poetry reflected her deep respect for those traditions:

The Bush was their home

They loved the smell of wild flowers

Because Nature has taught Aboriginals how to live in their own way.

For instance, when the drought is on the land

Each tribe knows how to find water

They have learnt it from animals and birds

Because animals, birds and tribes were the first created by Mother Nature in this land They understood each other. ${ }^{52}$

\footnotetext{
49 Australia, Senate Standing Committee on Constitutional and Legal Affairs, Reference: An examination of the feasibility, whether by way of constitutional amendment or other legal means of securing a compact or 'Makaratta' between the Commonwealth Government and Aboriginal Australians, Official Hansard transcript of evidence, 1983: 142. In 2010, a war memorial was opened at Mapoon to commemorate the World War II Army and Navy service of 16 Mapoon men, as well as 14 who served in the Civil Constructional Corps and community members who assisted Allied air crews.

50 'Survival Project', Bauxite Bulletin, no. 832 (13 May 1983): [2].

51 'M.A.P'. in Napranum Cha: Weipa South, no. 3 (December 1985-January 1986): 24.

52 Jean Jimmy, A history of Mapoon. Unpublished printed collection of Jean Jimmy's writing, copy given to the author by Jean Jimmy in July 1975.
} 


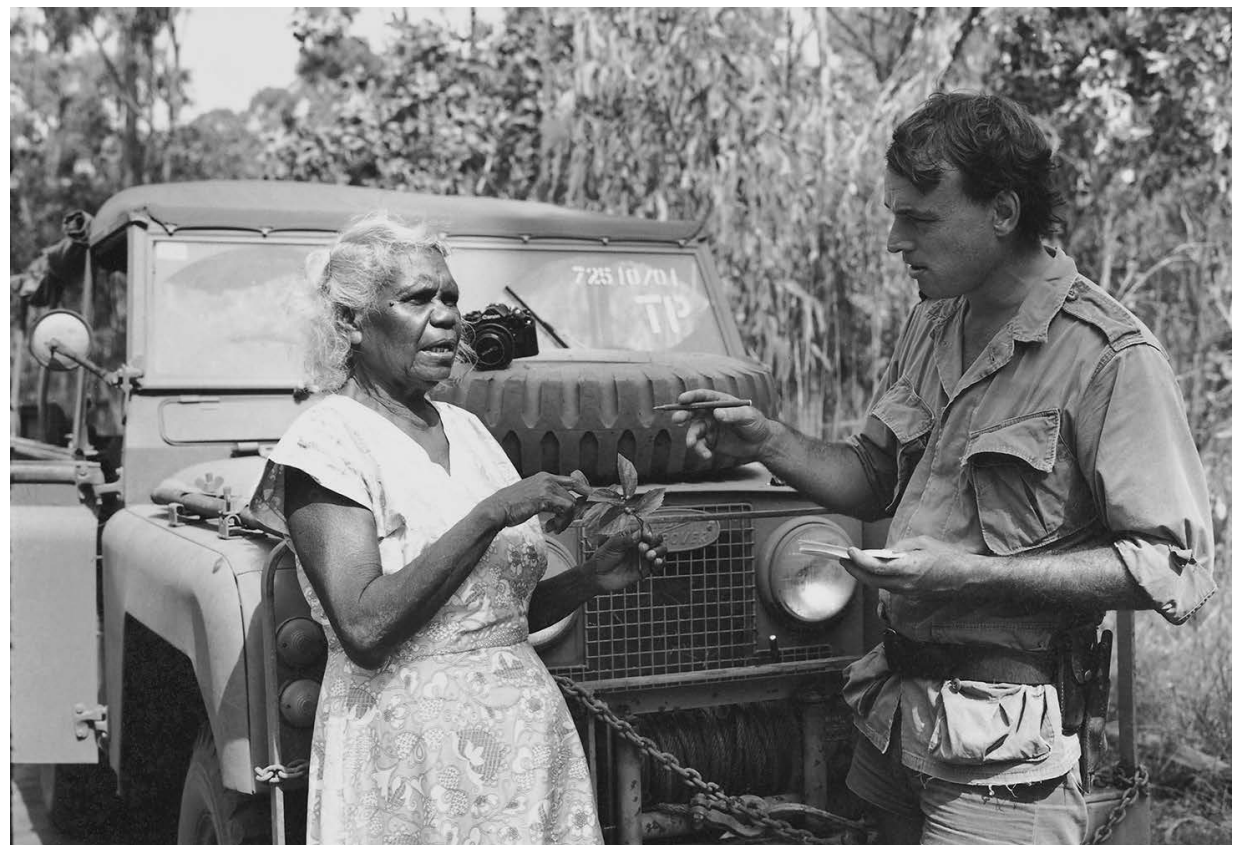

Figure 2: Jean Jimmy with Captain Les Hiddins, Australian Army survival specialist, May 1983.

Source: Photograph published in Bauxite Bulletin, no. 832 (13 May 1983): [1].

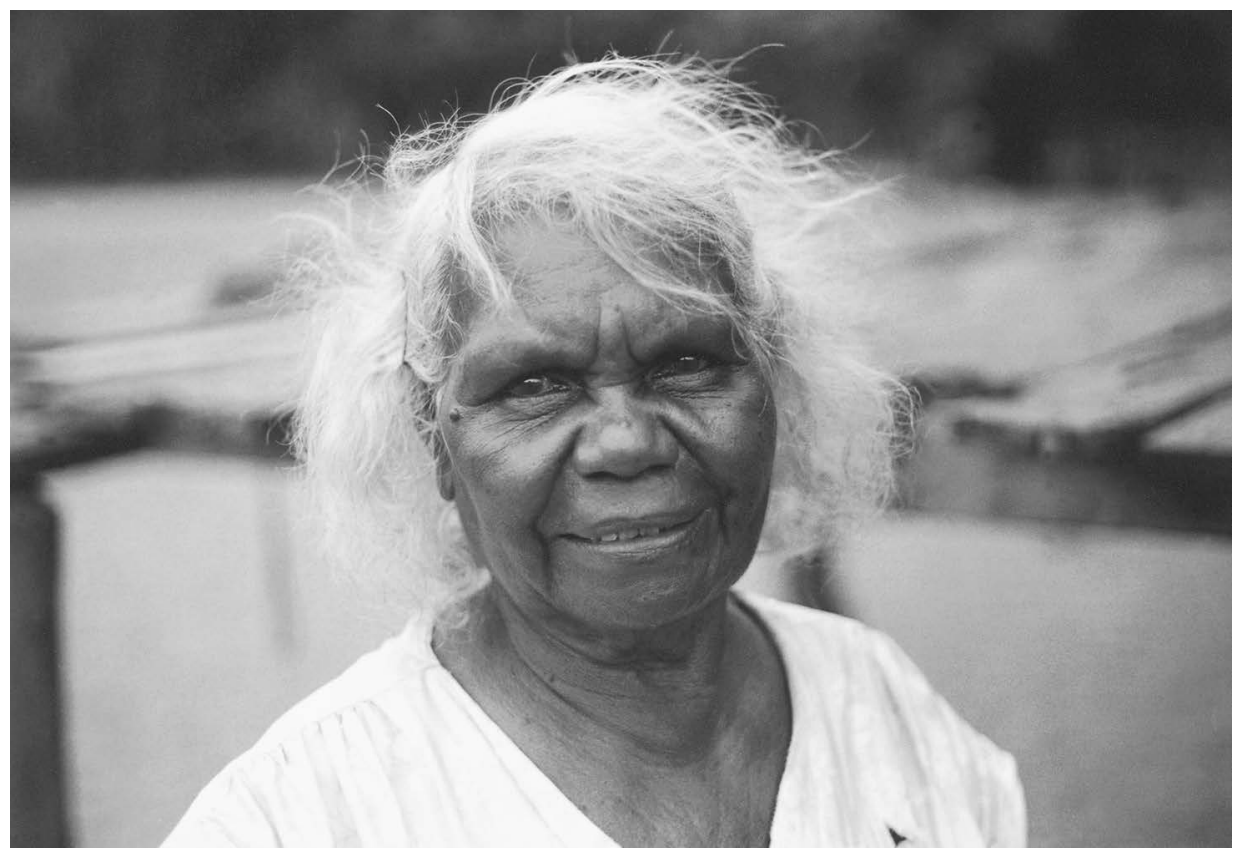

Figure 3: Jean Jimmy at Mapoon, 1984.

Source: Portrait photograph by Charles Birkett in the possession of the author. 
At Napranum on 26 April 1989, Jean Jimmy was an honoured guest of the then Queensland minister for community development, Bob Katter junior, at a ceremony to present the Deed of Grant in Trust over 183,960 hectares of former Mapoon Aboriginal Reserve lands to six Mapoon community trustees, including her only daughter Constance Annabel Cooktown..$^{53}$ Small-statured, and with great courage, determination and grace, Mrs Jimmy had inspired her people's struggle for their land and had won her fight with the Queensland Government. Predeceased by her husband on 11 December 1975 and survived by Constance, Jean passed away at Weipa Hospital on 17 October 1991 and was buried at the Mapoon cemetery (Musgrave outstation). ${ }^{54}$ Her headstone unveiling ceremony was held at Mapoon on 26 June $1999 .{ }^{55}$ A 1984 photographic portrait of Jean Jimmy by Charles Birkett at Mapoon is displayed in the foyer of the Mapoon Aboriginal Shire Council offices and the Mapoon Land \& Sea Centre is named in her honour. ${ }^{56}$

\footnotetext{
53 'Mapoon People Given Land Title', Bauxite Bulletin, no. 1135 (26 April 1989): 1.

54 The date that Gilbert Jimmy passed away, 11 December 1975, is noted in his Department of Aboriginal and Island Affairs file, 8G/267, Box 334, Item ID 725422, QSA. The Queensland Registrar-General does not hold a death registration for Ann Jean Jimmy. 'Mapoon Elder Passes Away', Bauxite Bulletin, no. 1262 (25 October 1991): 2; information transcribed from Ann Jean Jimmy's headstone, Mapoon cemetery.

55 The author attended this ceremony. (Note: Reference to this ceremony has been included because unveiling ceremonies are a very important part of the Mapoon people's cultural life and grieving processes.)

56 The Jean Jimmy Land \& Sea Centre was officially named by Ms Linda Cooktown, in the presence of Mapoon Elders and Senator Jan McLucas, on 16 November 2013. The centre employs local Indigenous Rangers whose responsibilities include management and protection of the cultural and environmental heritage of the Mapoon land and sea country. They are carrying on the traditional ways so much at the heart of Jean's life's work.
} 
This text is taken from Australian Journal of Biography and History: No. 1, 2018, published 2018 by ANU Press, The Australian National University, Canberra, Australia.

doi.org/10.22459/AJBH.2018.04 